Modern Asian Studies 53, 2 (2019) pp. 633-659. @C Cambridge University Press 2018. This is an Open Access article, distributed under the terms of the Creative Commons Attribution licence (http://creativecommons.org/licenses/by/4.o/), which permits unrestricted re-use, distribution, and reproduction in any medium, provided the original work is properly cited.

doi:10.1017/Soo26749X17001093 First published online 3 October 2018

\title{
Poor Man's Crop: Evading opium monopoly*
}

\author{
GUNNEL GEDERLÖF \\ Linnaeus University \\ Email: gunnel.cederlof@lnu.se
}

\begin{abstract}
Research on opium in colonial India has so far mainly focused on the competing Malwa and Bengal opium currents under the control of the Sindia and Holkar families and of the British East India Company, respectively. The historical trajectory has tended to emphasize the implementation of a draconian and allencompassing British monopoly. This study joins the emerging efforts to search the regional histories on the margins of the strongest players' actions on the global scene. It aims at nuancing the narratives by focusing on a region away from such centres. The study investigates the local cultivation and usage of opium in Rangpore district-a region in north Bengal that had recently been badly affected by a severe flood. Here, the drug was extensively used and the lucrative trade with neighbouring states gave small-scale cultivators an income also under hard environmental conditions. The fact that production and trade were small-scale, fragmented, and made use of markets in Cooch Bihar, Assam, and Bhutan impeded British attempts at getting in control of production and trade.
\end{abstract}

\section{Introduction}

Opium was an old crop in India when it hit the global market via combined illegal and legal channels of mercantile trade to China in the late eighteenth and early nineteenth centuries. Profits climbed sharply from 1800 to 1830 , and the British East India Company (EIC) challenged the opium-producing states in western India by enforcing a monopoly over the production and marketing of the drug. The transition had severe consequences for regional cultivation and

* I am grateful to Neil Price for encouraging me to write this article and to Tanika Sarkar for her comments on an early version of the manuscript. 
domestic use of opium. There were imperial and local logics of the trade and different interests clashed also within the Company.

Research on opium in colonial India has so far mainly focused on the competing Malwa and Bengal opium currents and has tended to emphasize the introduction of a draconian and all-encompassing British monopoly. Whereas this may be the general logic on a grand scale, enquiring into regional logics away from the strongest players on the global scene nuances such narratives. This study investigates the local usage and cultivation of opium in Rangpore-a region in Bengal that had been turned over to the EIC as part of the dewani grant in 1765 , when the Company was made a governor under the Great Mughal in Delhi. Two decades later, Rangpore had been badly affected by a severe flood. Here, the drug was extensively used and the lucrative trade gave small-scale cultivators an income also under hard environmental conditions. Cultivators in Rangpore largely disregarded the British monopoly. The numerous avenues for unlicensed trade into neighbouring Assam, Bhutan, and Cooch Bihar were difficult to control. Studying the local economy and ecology of opium brings nuances to the dominant historical narratives and shows the diversity of production and usage. Set in a larger frame of Indian opium production, this article brings out the local and regional politics in north Bengal and the neighbouring territories. It targets the year 1823 , as it was the year when the EIC changed its policy and enforced a stricter monopoly.

Opium was cultivated and consumed in India already in the eighth century when Arab traders introduced the drug. It was grown for domestic consumption in the heartland of Mughal India long before it was turned into a profit-making export product of the European mercantile corporations. However, in the seventeenth century, it had become one of the principle crops in Bengal. Merchants in the Dutch East India Company exported the drug to Batavia and Canton, and production and trade expanded dramatically. A report from 1727 noted that 'Patana [Patna] produces also so much opium that [sic it] serves all the countries in India with that commodity'. ${ }^{1}$ This was also the time when the EIC entered the trade. Subsequently, it was made

\footnotetext{
1 'Note on the History of Opium Trade in India and of the Trade in It with China', 1894, Royal Commission on Opium. Vol. 7, Part 2, App. A, in Binoy B. Chaudhuri, Growth of Commercial Agriculture in Bengal (I757-190o) (1; Calcutta: R. K. Maitra and Indian Studies Past and Present, 1964), p. 3; George Watt, Economic Products of India (VI; London: W. H. Allen \& Co., 1891), pp. 33-34.
} 
a keystone of triangular trade between India, China, and Britain in the nineteenth century and profits sky-rocketed. ${ }^{2}$

Most opium was grown in the western-Indian Malwa opiumproducing region and within a north-south span of 240290 kilometres, along the eastern Gangetic valley from Agra and 8 oo kilometres east. In the late eighteenth century, when the EIC had attained territorial rights in Bengal and Bihar, most of the opium production along the Ganges, known as 'Bengal opium', came within their jurisdiction whereas the Malwa crops remained under indigenous rulers. The most influential were the Sindia and Holkar families. Of the 24 princely states of Malwa that constituted the Madhya Bharat territory, these two families controlled three-quarters of the land. Competition for market control and the EIC's monopoly politics are to a large extent explained by the Malwa-Bengal divide. Malwa opium, sold at half price, challenged the Company's control of high-quality Bengal opium, and Malwa had a niche of its own in the Chinese market. ${ }^{3}$

The British victory in the Anglo-Maratha War in 1818 changed the balance. Even though the British did not annex all opium-producing Maratha states, they were able to put enough pressure on them, since they controlled the dominant port of export-Bombay. However, the complete control of the Indian opium market remained elusive until Sindia's army was disbanded in 1843 . Opium had then supported the Sindia economy for half a century. As concluded by Amar Farooqui, it was more than a matter financial resource: 'conceding a monopoly to the company was a serious infringement of the internal autonomy of the Sindia state. ${ }^{4}$

${ }^{2}$ John F. Richards, 'The Indian Empire and Peasant Production of Opium in the Nineteenth Century', Modern Asian Studies, 15(1) (1981), pp. 59-82, 61; Amar Farooqui, Smuggling as Subversion: Colonialism, Indian Merchants and the Politics of Opium (New Delhi: New Age International Ltd, 1998), pp. 3-4; Sugata Bose, European Commercial Enterprise in Pre-Colonial India (The New Cambridge History of India, 2: 5; Cambridge: Cambridge University Press, 1998), pp. 282-283; Om Prakash, European Commercial Enterprise in Pre-Colonial India (Cambridge: Cambridge University Press, 1998), pp. 282-284; Watt, Economic Products of India, p. 24.

${ }_{3}^{3}$ Malwa, traditionally a region in central India. Opium grown in this region became known by its name. Farooqui, Smuggling as Subversion, pp. 25-26, 6o; Amar Farooqui, Opium City: The Making of Early Victorian Bombay (Gurgaon: Three Essays Collective, 2006), pp. 19-20; Richards, 'The Indian Empire', pp. 65, 69-7o. 'Bengal opium' meant opium manufactured at Patna and Ghazipur. It was distinct from Turkey, Malwa, and other opium varieties. Watt, Economic Products of India, p. 55 .

${ }^{4}$ Richards, 'The Indian Empire', p. 65 ; Amar Farooqui, Sindias and the Raj: Princely Gwalior c. I80o-I850 (New Delhi: Primus Books, 2011), pp. 88-92, $114^{-11} 15$. 
However, local consumption went far beyond these regions. In the 1820 s, as part of a policy to enforce monopoly of production, EIC officers went in search of illegal cultivation in Rangpore district in north Bengal. Reports show how they were dumbfounded at the extent of production. In view of 200-300 per cent profit compared to the 10 per cent that cultivation with an EIC licence would bring, and with minimal risks of being caught, illicit production and sale were routine. ${ }^{5}$

The stricter policy aimed at enforcing EIC monopoly was only possible after the territorial gains in the 1818 war and it was a measure taken to block the cheaper Malwa opium from reaching the Chinese market. Hereafter, indigenous states had to sell their produce to the Company at specified quantities and fixed prices. It was expected not only to reduce their profit, but also to limit the cultivation of poppy in their territories. The effect, however, was quite the reverse. The Malwa-producing states not only cashed the compensation paid for preventing illicit trade; they also supervised large quantities of illegal opium that were transported from the fields to the ports, avoiding British territories. In addition to the dominant producers, the rulers of Sindia and Holkar, also cultivators who did not aim for the Chinese market, continued to sell to unlicensed traders at closer range. In north Bengal, opium found its way into Assam and Cooch Bihar, and it was traded locally in the Rangpore district. ${ }^{6}$

Cultivation and trade in opium had a long history of market control prior to the British conquest of Bengal and Bihar. Opium merchants in Patna formed a syndicate that controlled the chain of production from cultivation to export by means of advance payments and fixed prices on crude opium set by the syndicate. As their control was not complete, a substantial amount of opium also found its way to the market via smaller traders. In the early eighteenth century, as the Mughal empire began to weaken, the syndicate's restrictions on opium cultivation faded and British agents made agreements directly with the cultivators. From the time of the EIC's victory at Plassey in 1757 to 1765 , when the Mughal granted diwani rights in landed revenues in Bengal, Bihar, and Orissa to the Company and made them the governor of this large region, agreements between the British and

\footnotetext{
${ }^{5}$ Oriental and India Office Collections (hereafter OIOG), Bengal Board of Revenue Lower Provinces, Cons. 6.5.1823, No. 32, To Secr. to Board of Revenue, from David Scott, Commissioner Cooch Behar, 13.8.1822, para. 8.

${ }^{6}$ Chadhuri, Growth of Commercial Agriculture in Bengal ( $\left.1757-1900\right)$, p. 14; Farooqui, Smuggling as Subversion, p. 19.
} 
the opium producers marginalized the Dutch and French companies. Their shares diminished over time and the monopoly of opium was effectively taken over by the EIC. ${ }^{7}$

At first, Company merchants at Patna formed the Patna Council for the purpose of exercising control of the trade. In 1773, the EIC Governor General Warren Hastings moved control to the Company itself. From here on, cultivators were only permitted to grow opium for the EIC and in quantities decided by advance payments. Rigorous penalties were put on illicit cultivation and trade. In 1797, the Company pulled the strings even tighter and the contract system was replaced by an agency with two opium agents: one placed at Patna and the other at Benaras. Regulation VI of 1799 prohibited private cultivation of poppy and legislated that the drug was to be cultivated on a specified size of land and result in a fixed amount of opium to be delivered to the opium agent at a fixed price. Any diversion from this regulation, whether illegal cultivation, sale, or smuggling, was met by severe punishments. ${ }^{8}$

The following decade and a half, from 1798-99 to $1816-17$, the price of Bengal opium rose by 433 per cent. Speculation in the crop soared. $1815^{-16}$ became a peak year, with prices at $5^{86}$ per cent of the year of the regulation. Facing high prices, consumers looked for alternative sources, and Malwa and Turkey opium reached the Chinese market together with illicit Bengal opium. Trade in the latter was significant, since the Company-controlled Bengal opium only amounted to half the total import of opium into China. Since the EIC only allowed the Bengal quality to be shipped out of Bombay, all other opium found its way to China mainly via Portuguese ports. The Malwa opium was transported via an elaborate network of routes from the native states to the coast. From 1819, after the defeat of the Mahratta kingdom, one of the Portuguese ports, Damao, had practically monopolized opium exports from Portuguese India to Macao and the Chinese markets. It had the advantage of being shielded by the Thar Desert and was therefore difficult to access by the British forces. Claude Markovitz identifies a four-tier system in the Malwa opium trade. First came the cultivation and the preparation of the drug for transport-a tier occupied by peasants and financiers, from village money-lenders to city bankers (mostly Marwari). In

\footnotetext{
${ }^{7}$ Richards, 'The Indian Empire', p. 63.

${ }^{8}$ Chaudhuri, Growth of Commercial Agriculture in Bengal (I757-190o), pp. 7-8; Richards, 'The Indian Empire', pp. 63-64.
} 
the second tier, agents for big Indian firms based in Bombay or Ahmedabad bought semi-refined opium and had it further refined and packed into chests for transportation. In the third tier were officials from native states who either protected merchants or traded themselves and, finally, the uppermost tier encompassed the urbanbased big capitalists. Both Indian and European traders operated in the Malwa opium trade. Markovitz notes that European capital primarily had been involved in the initial stages of Malwa production. It was subsequently taken over by Indian capitalists, mainly Parsis and Gujarati Hindus in Ahmedabad and Bombay. ${ }^{9}$

In an act to protect the monopoly and root out Malwa opium from the market, the EIC decided to buy up Malwa opium, lower the price, and meet the full demand of the Chinese market with Companycontrolled opium. An opium agent was ordered to make the purchases and sell at prices that would elbow competitors out of the market. As a consequence, the agent, not knowing the situation well enough, bought anything he could lay his hands on. Rumours spread that the British were buying up all available opium, which made the cultivators grow unprecedented amounts of the drug. The surplus opium went into illicit trade. $^{10}$

The EIC's dependence on opium and their ambition to go to any length to secure the opium revenues came to a breaking point in the early $1820 s$. In his minute on the revenues in India, in 1823 , the Governor General John Adam estimated the total surplus to be Rs 23 million. The three presidencies showed some significant differences. Madras contributed Rs 1.6 million, whereas Bombay showed a deficit of more than Rs 7 million and Bengal a surplus of close to Rs 27 million. Madras's economy was suffering under the impact of Britain's industrial revolution, which strangled the textile market and made prices collapse. A decade-long depression followed. Bombay's deficit was primarily explained by the city's port from where the bulk of the Company's opium export was shipped. Some of the purchases

\footnotetext{
${ }^{9}$ Average selling price per chest, 1798/99: Rs 414, 1814/15: Rs 2,427, 1816/17: Rs 1,795. One chest equalled 160 pounds or 72.57 kilograms. From approx $185^{\circ}$, the more commonly used chest was the revised Malwa chest, which equalled 140 pounds, 63.5 kilograms or 1.05 picul. The latter was the unit for opium used in China. Chaudhuri, Growth of Commercial Agriculture in Bengal (I757-I9oo), pp. 9, 12-13; Farooqui, Smuggling as Subversion, Chapter 1, n. 21. Claude Markovits, 'The Political Economy of Opium Smuggling in Early Nineteenth Century India: Leakage or Resistance?', Modern Asian Studies 43(1) (2009), pp. 98-101.

${ }^{10}$ Chaudhuri, Growth of Commercial Agriculture in Bengal (I 757-I9oo), pp. 13-14.
} 
in one year could only be sold in the next, which resulted in a deficit in the accounts. Bengal, however, was the cradle of opium production. Put together, the Company treasury showed a large surplus. Having successfully repaid parts of an old debt and reduced future charges, disposing of such a surplus became a bit of a headache for the Company. Bengal suffered from scarcity of silver bullion, which paid for imports to Britain, and no further bullion was to be sent there. The highest board of the Company, the Court of Directors, also advised against purchasing bills on England from private merchants or to drain the resources by strengthening the Canton treasury. It remained to make investments in India's civil and military establishments and public institutions. ${ }^{11}$

In 1823 , failing to secure the opium monopoly, the Company decided to invite the heads of the opium-producing states into the policy and allow them a share of the profit. In return for a share, unlicensed opium had to be confiscated and the area under cultivation was restricted. Hostile reactions followed. The 'share' in profit was illusory and losses spoke for themselves, as when the head of the Kotah state lost Rs 6o,ooo when the trade died down. Such a loss had political consequences. As concluded by B. B. Chaudhuri, '[t]he restrictive system forcibly deprived all the important groups connected with poppy cultivation and opium trade of their normal gains and the economic dislocation of the entire society was nearly complete'. ${ }^{12}$

During the following years, also within the Company, criticism of the restrictive system mounted. Chaudhuri deems the political consequences as more severe than the economic and the main reason for why the system was abandoned. The indigenous rulers, the cultivators and merchants alike, may not only have revolted against the opium controls; 'the entire political system was in danger.' ${ }^{\text {, }}$

These were the general trends of opium production and of commerce on a large scale. At the outskirts of the Bengal and Malwa opium

${ }^{11}$ OIOC, European Manuscripts, John Adam's Collection, Extract Bengal Salt and Opium Consultations 29 May 1823, No. 1, Minute of the Honourable John Adam, Governor General, 22.5.1823; Gunnel Cederlöf, Founding an Empire on India's NorthEastern Frontiers, I790-I 840: Climate, Commerce, Polity (New Delhi: Oxford University Press, 2014), pp. 108-109; H. V. Bowen, 'Bullion for Trade, War, and Debt-Relief: British Movements of Silver to, around, and from Asia, 1760-1833', Modern Asian Studies 44(3) (2010), pp. 445-475, 448-45o, 52, 57-61,64-65; David A. Washbrook, 'South India 1770-1840: The Colonial Transition', Modern Asian Studies 38(3) (2004), pp. $479^{-} 5^{16}, 5^{\mathrm{O}} 7-5^{\mathrm{o}} 8$.

${ }^{12}$ Chaudhuri, Growth of Commercial Agriculture in Bengal (I 757-190o), pp. $15^{-16}$.

${ }^{13}$ Ibid., p. 17 . 
conflicts were also the small producers and petty traders who tried to make the best of opportunities. Compared to the China market, theirs was a limited one. Yet the EIC officers, collectors, and magistrates aimed at restraining also these businesses. They may have been smallscale and marginal but, taken together, they turned a flood of profit away from the Company and the officers went into the interior of the district to wipe out the weed of illicit cultivation and trade.

\section{The economy of opium ecology}

Opium cropping coloured parts of Bengal in gleaming red fields. But the ecology of opium production raises some questions. Opium is a thirsty plant that grows best in well-manured sandy-loam soils. Newly sown fields require water as soon as the plant appears above ground and irrigation must continue until harvest. However, if the fields border on rivers or wetlands, irrigation may not be necessary, since the soils will retain the moisture several months after the monsoon in the late autumn. ${ }^{14}$

The monsoon was a crucial condition for the success of opium in Bengal. The agrarian economy was shaped by the climate: by the annually flooding rivers, the seasonal lakes, and the continuous fertilization of riverbeds from the tons of mineral-rich silt that was deposited every year. As the Brahmaputra leaves Assam and enters the Rangpore district, it sends an annual average of 6o1,400 cubic feet of water per second. During a monsoon, it increases to more than 2.5 million cubic feet per second and carries over the entire river course 13 million tons of sediment per day. The sediment contains sand, silt, and clay, which deposit their substance in different ways in the river bed. While the coarse sand is low in organic matter and takes away the productive capacity of soil, silt has finer micronutrients that fertilize the floodplains. This was the precondition for successful opium cultivation. The enormous movements of water and sediment continuously reshaped the riverine landscape and the British officers observed its effects. 'One person's property being carried away, and another's enlarged, while the tax of both continues the same', in Francis Buchanan-Hamilton's words. ${ }^{15}$

${ }^{14}$ Watt, Economic Products of India, pp. 61-62.

${ }^{15}$ Arupjyoti Saikia, The Unquiet River: An Environmental Biography of the Brahmaputra (New Delhi: Oxford University Press, forthcoming), Chapter 1. 
Buchanan's survey of Rangpore district in 1809 was the first since James Rennell made cartographic investigations in 1765 . The changes that had taken place between the two were so significant that Rennell's maps were of no use to Buchanan. In a longer timeperspective, Richard Eaton observes large-scale landscape changes. From the sixteenth to the eighteenth centuries, there was a gradual shift eastwards of the Ganges. Having entered the Bay of Bengal in the westernmost part of the delta, over time, in 1787 , the Ganges discharged into the River Padma, close to the Brahmaputra in the eastern part of the delta. The large transition of the Ganges together with the waters of the Brahmaputra shaped different ecological contexts in Bengal. While the western part of the delta was in a process of slow decay, forming old alluvium, the eastern part benefitted from a constant flooding and fertilization that produced new alluvium. Together with the geological shift, also economic life gravitated eastwards when wet-rice cultivation became possible on a larger scale in east Bengal. During this period, Bengal was integrated into the Mughal empire. ${ }^{16}$

However, Buchanan faced the result of a dramatic event when he travelled in Rangpore district in 1809 . In 1787 , a severe flood hit all of Bengal. The magnitude of the disaster was immense and Rangpore was in its eye. The unusually strong monsoon had been accompanied by a storm and a deluge that had changed the course of the entire river system. Large rivers, such as the Tista, drastically changed direction, not to mention all the minor water courses that criss-crossed the country. The most dramatic consequences had been the result of the Brahmaputra shifting from its eastern bend into Mymensing to its present course, running straight south towards the Bay of Bengal. Massive amounts of water had broken the walls of silt, causing enormous devastation and death. Buchanan reported that half of both people and cattle had been swept away near the new course of the Tista when it flooded right across Rangpore district and

${ }^{16}$ OIOC, MMS Eur, D74, Buchanan-Hamilton Collection, List of papers respecting the district of Ronggopur [Part 1], Book 1, Chapter 2, General Remarks; Richard Maxwell Eaton, The Rise of Islam and the Bengal Frontier, I 204-I76o (Comparative Studies on Muslim Societies, 17; Berkeley: University of California Press, 1993), pp. xxvii, 359, 21 7-2 1 8, 20-24; see also Radhakamal Mukherjee, The Changing Face of Bengal: A Study in Riverine Economy (Calcutta University Readership Lectures; Kolkata: University of Calcutta, 2009 [1937]); Birendra Nath Ganguli, Trends of Population and Agriculture in the Ganges Valley (London: Methuen \& Co., 1938), p. 9; Gederlöf, Founding an Empire, pp. 22-23. 
discharged into the Brahmaputra instead of running south towards the Ganges. The new Tista came to define the boundary between Dinagepore district in the west and Rangpore district in the east. ${ }^{17}$

When Buchanan reported from Rangpore, 20 years after the disaster, it needs to be understood in view of the consequences of the flood and the low population density in the district. Buchanan writes: 'The soil is so light, and the rivers in descending the mountains have acquired such force, that frequent and great changes are unavoidable, so that whole channels have been swept away by others, and new ones are constantly forming.' It took three decades for the landscape to stabilize. From the 1770 on onwards, there was a general, slow but steady population increase in Bengal. However, in regions such as Rangpore, far from the delta and the major economic centres, it was an insignificant growth. Sugata Bose notes that the population in Rangpore rose by only 15 per cent from 1809 to the 1870 os. ${ }^{18}$

Buchanan's description of the ecology of Rangpore is a necessary context for discussing the cultivation of opium in the early 1820 , even though he travelled in the region about one decade earlier:

The common ash coloured free soil of this district is in many places very sandy and poor, and seems to have much less tendency to produce the luxuriant vegetation of trees and bushes, so common in Dinajpur [sic west of Rangpore and the site of the old Tista]. In many parts indeed, that are high, nothing will grow on it but a short miserable pasture, or a few stunted trees, so that the country is perfectly clear without any exertion on the part of the inhabitants, and the advantage of having the country clear is evinced, from the little annoyance, that the people of such parts of the district suffer from destructive animals. Where the land is low, on the contrary, and inundated during the rainy season, and where in such situations cultivation has not been extended, everything is overwhelmed with reeds, which shoot up with an astonishing vigour, and form thickets, that are almost impenetrable to man. Numerous destructive animals find there a secure retreat, and spread their devastation to a considerable distance. ${ }^{19}$

${ }^{17}$ OIOC, MMS Eur, D74, Buchanan-Hamilton Collection, List of papers respecting the district of Ronggopur [Part 1], Book 1, Chapter 2, General Remarks; Sugata Bose, Peasant Labour and Colonial Capital: Rural Bengal since I 770 (The New Cambridge History of India, 3: 2; Cambridge: Cambridge University Press, 1993), pp. 11; Cederlöf, Founding an Empire, pp. 22-23.

${ }^{18}$ OIOC, MMS Eur, D74, Buchanan-Hamilton Collection, List of papers respecting the district of Ronggopur [Part 1], Book 1, Chapter 2, Of the Rivers; Bose, Peasant Labour and Colonial Capital, p. 23.

${ }^{19}$ OIOC, MMS Eur, D74, Buchanan-Hamilton Collection, List of papers respecting the district of Ronggopur [Part 1], Book 1, Chapter 1, Section 1. 
The spread of sand over large distances across fertile land was a major problem following a severe flood. The annual sedimentation that discharged silt on the river beds, the chars, provided good soil for cultivation when the water subsided. But the sand that spread further inland could also bring down fertility or totally devastate the best lands. When Buchanan surveyed this territory, the old river beds, which had now gone dry due to the changed flows, laid bare and infertile. The old Tista had turned into an 'immense sandy channel [which] announces its recent grandeur'. ${ }^{20}$

Knowing that opium requires fairly good soils, it may be surprising to see the extent to which opium was cultivated in Rangpore in the 1820 . The district was dominated by medium and large zemindari estates-landlords who let the land to tenants. However, for a poor cultivator, even very small amounts would produce an income that no other crop could match. Seen in this light, opium was a poor man's crop when cultivation took place under restrained environmental circumstances. It is also significant that the best soils in Rangpore district were found in Barband and Niz Behar parganas, next to the Brahmaputra, where irrigation would not be required. The plant had a long history in the region. It had been in circulation long before European commercialization of the crop for export. ${ }^{21}$

Opium for the Indian market was made and marketed in many forms. The sap could be condensed from the unripe capsules, which resulted in a crude form of opium. Moisture and soluble ingredients, known as pasewa, could be drained from it. The poppy petals were also collected and used. The dry stems and leaves could be made into a powder. The capsules were used in different ways, as were the seeds. The seeds could be used both pealed, in sweetmeats and curries, and with the peal on, which made it bitter and narcotic. Opium oil was also used in several different forms and for different purposes. $^{22}$

${ }^{20}$ OIOC, MMS Eur, D74, Buchanan-Hamilton Collection, List of papers respecting the district of Ronggopur [Part 1], Book 1, Chapter 2, Of the Rivers; Kuntala Lahiri Dutt, Dancing with the River: People and Life on the Chars of South Asia (New Haven: Yale University Press, 2013), Chapter 1.

${ }^{21}$ OIOC, MMS Eur, D74, Buchanan-Hamilton Collection, List of papers respecting the district of Ronggopur [Part 1], Book 1, Chapter 2, Condition and manner of living; Bengal Board of Revenue, Cons. 28.5.1822, No. 101, To Board of Revenue, from R. P. Nisbet, Collector of Rungpore, 7.5.1822, para. 1; Edward George Glazier, $A$ Report on the District of Rungpore (Calcutta: Bengal Secretariat Press, 1876), p. 34 .

${ }^{22}$ Watt, Economic Products of India, pp. 19, 77-78. 
With a drug as valuable as opium, any vendor would try and make the most of it. Opium from Calcutta arrived as cakes covered in leaves that would prevent them from drying and losing weight. Vendors complained that it was difficult to dispose of the drug in this form, and they were granted permission to remove the cover. Two effects showed up immediately in the Bengal Department of Customs, Salt and Opium's accounts. Once the cover was removed, it became easy to mix the drug with other substances, making it difficult to detect for an untrained eye. Further, without the cover, opium began to evaporate and the Collector of Rangpore reported the loss of weight as wastage to a displeased revenue department.

Soon enough, he also shared a remedy. In a very detailed note, he described a recipe for separating opium from leaves through boiling and draining. Adding a word of caution, he advised that the earthen pots that were used in the process always had to be new. This would preclude natives of high caste to object that the opium had become impure from being boiled in an impure vessel. ${ }^{23}$

Even though smoke opium never took complete hold of the Indian consumers as it did among the opium addicts in China, in Rangpore, it was smoked as mudut or, as it was known in other parts of India, madak. The opium was boiled into the consistency of a paste and mixed with shredded and fried betel leaves or, sometimes, guava or other plants. It was thereafter dried. Small quantities of opium juice could also be added to the leaves and mixed in a hot vessel. The mixture was thereafter formed into small balls that were smoked. But smoke opium was expensive and required much more time to consume. The Report of the Committee on Certain Aspects of Opium and Ganja Consumption (1878-79) stated that smoke opium increased in Assam as a result of the prohibition of poppy cultivation in 1860 . According to them, a moderate estimate would be that half of all opium consumers smoked the drug at the time of the enquiry, and there was no difference between opium users in tea gardens and the population indigenous to Assam. Their estimate for the consumption of smoke opium in Assam before the prohibition was only about 5 per cent. ${ }^{24}$

${ }^{23}$ OIOC, Bengal Board of Revenue, Cons. 28.5.1822, No. 10o, To R. Hunter, from R. P. Nisbet, Collector of Rungpore, 1.5.1822; Cons. 5.7.1822, No. 71, Statement of wastage \& c. occurring on opium to the 3oth April 1822 in Zillah Sylhet, 9.5.1822, and No. 1994, 5.6.1822; Cons. 6.8.1822, Nos. 96, To Collector of Sylhet, from R. Hunter, Secretary Board of Revenue, 6.8.1822.

${ }^{24}$ OIOC, MMS Eur, D74, Buchanan-Hamilton Collection, List of papers respecting the district of Ronggopur [Part 1], Book 1, Chapter 2, Condition and manner of living; 
Poor people used opium in a different way. They took the ripe capsules of the paste of poppy. After the seeds had been removed, five dry capsules were put in cold water for 20 minutes. They were then squeezed by hand and strained through a cloth, and the liquid was drunk immediately. The dry capsules could also be parched and reduced to powder, which could be taken with cold water at any time. Buchanan reported that people consumed any of these portions twice or three times per day. In spite of intoxication, people were said to be able to work. But omitting a single dose would make them feeble and stupid. As Buchanan saw it, if only people ate well, the drug would do no harm. Even throughout the nineteenth century, the medicinal effects of opium were often claimed to surpass the harmful effects of the drug. As an anodyne and antispasmodic drug taken in smaller doses, its morphine ingredient reduces pain and relieves agony; its impact on the intestines slows the movement of the gut, which reduces effects of diarrhoea and dysentery. As it also suppresses the brain centres that control the coughing impulse, it seemed to have miraculous effects on all kinds of disease. Opium was seen as a necessity and recommended as a protection against fever, in particular in tropical climates. It was rather put forward as a matter of moral aptitude whether or not to be able to keep the dose at levels below addiction. The downsides were obvious-nausea, constipation, depressed respiration, the initial euphoria turning into paranoia, and, not least, addiction. ${ }^{25}$

About a decade after Buchanan's visit, the scene had changed. The opium monopoly had never really taken hold of Rangpore; most of the opium was grown outside EIC control. In 1822, the Rangpore Collector, on tour to destroy as much illicit opium as possible and to set up shops for opium under license, explained:

In this district opium is consumed to an extent hardly to be conceived by nonresidents. In every village by far the greater number of families consumes a daily quantity, even children of eight and ten years old, are frequently allowed

Bengal Board of Revenue, Cons. 28.5.1822, No. 101, To Board of Revenue, from R. P. Nisbet, Collector of Rungpore, 7.5.1822, para. 1. Assam State Archives, Report of the Committee Appointed to Fnq. into Certain Aspects of Opium and Ganja Consumption I878-79, paras $3-5$.

${ }^{25}$ OIOC, MMS Eur, D74, Buchanan-Hamilton Collection, List of papers respecting the district of Ronggopur [Part 1], Book 1, Chapter 2, Condition and manner of living; Bengal Board of Revenue, Cons. 28.5.1822, No. 101, To Board of Revenue, from R. P. Nisbet, Collector of Rungpore, 7.5.1822, para. 1; ibid., at 41; Julia Lovell, The Opium War: Drugs, Dreams and the Making of China (London: Picador, 201 1), pp. xxii, $45^{8,} 3^{2}$ pp. of plates, 19-20, 34 . 
a portion with their parents, therefore the establishment of shops, will not be encouraging the consumption of the drug, but merely occasioning the present consumers to purchase at legal instead of illegal shops. ${ }^{26}$

He does not seem to have shared Buchanan's more lenient view on the effects of opium: ' $[\mathrm{I}] \mathrm{t}$ is notorious that no persons once addicted to opium can ever give up the use of it.' The Collector echoed many earlier European reports. Anton Hove, travelling as a naturalist and making botanical observations in 1787 , noted that opium was a common beverage in Mughal India ${ }^{27}$ :

All these opium drinkers are, at 40 , the most miserable creatures the world supports. They are either hectic, or so nervous and spasmodic that they are hardly able to out-crawl a snail. They have, however, a convinced idea of its bad qualities, and in consequence said 'we would leave it off if we could, but on cessation for a little while we found ourselves so much reduced, and should perish if we had not recourse to it again. ${ }^{28}$

In 1797, when the opium agency was established, the EIC had decided only to cultivate opium on the best soils, and cultivation was prohibited in Rangpore, Purnea, Mongyr, Bhagalpore, and other districts where conditions for cultivation had been deemed too poor. Eighteen years later, in 1815 , the ban had been lifted since it had been without effect and production without a license thrived. The following year, a regulation was passed that compelled collectors to suppress clandestine sale and seize all contraband opium in their districts. This was easier said than done and the Rangpore Collector was not very successful. Just like his successors would later do, he singled out the high taxes as the main cause for illegal production. The fixed rate on both dry and wet opium was to blame. The Collector explained that the previous year's surplus could only be explained by excessive taxation and worked as an incitement for the cultivators to enter into illegal trade. Also, other opium-producing regions in Bengal reported the high taxes for causing defaulting payments. ${ }^{29}$

${ }^{26}$ OIOC, Bengal Board of Revenue, Cons. 5.3.1822, No. 1o, To the Board of Revenue, from R. P. Nisbet, Act. Collector of Rungpore, 28.1.1822, para. 7 .

${ }^{27}$ OIOC, Bengal Board of Revenue, Cons. 15.3.1822, No. 33, To the Board of Revenue, from R. P. Nisbet, Act. Collector of Rungpore, 7.2.1822, para. 4 .

${ }^{28}$ Watt, Economic Products of India, pp. 19, 34, 77-78.

${ }^{29}$ Regulation 13 , Section 83 and 87 , of 1816 . OIOC, Bengal Board of Revenue, Cons. 5.3.1 822, No. 10, To the Board of Revenue, from R. P. Nisbet, Act. Collector of Rungpore, 28.1.1822, paras 4, 6, 7, and Bengal Board of Revenue, Cons. 12.9.1820, No. 36, To G. Warde, Secr. to Government, from G. G. Blagrave, Collector of 
Barbund, the most productive of the parganas, was also known as 'notoriously refractory and turbulent'. People were said to disregard orders whether from the magistrate, police officers, or any other public functionary. Bounded by the Brahmaputra on its eastern border, there were plenty of boats for the large quantities that were exported to Mymensing, Dacca, and other neighbouring districts. According to the Collector, the cultivators ran into frustrations when they tried to cultivate openly. In most of Bengal, seeds were sown on lands near the village and, since initial investments were high, it required advance payments. Such payments not only facilitated the cultivation of the crop; they also provided the merchants making the advance to the farmer with the advantage of controlling the cultivation. In Barbund, the cultivators had even decided among themselves to plant without the outer wall of their houses and, in some cases, also within the house itself. To control the opium cultivation, the collectors needed intimate knowledge about the place and he needed to stay for long periods in the neighbourhood. This made him ask for two bungalows to be built: one in each of the most prosperous opium parganas, Barbund and Niz Behar. ${ }^{30}$

In 1822, the Collector reported that more poppy was cultivated illegally than when the opium agency existed, and he was immediately to leave for the interior parts of the district to destroy the plant before the drug had been extracted. Arriving in Camp Chandamary, where most of the poppy in the district was grown, he found that poppy was cultivated to a greater extent than he could have imagined ${ }^{31}$ :

In every village yet visited I have found poppy and tho' it is now, not more than 12 days since I left Rungpore, I have destroyed 130 Beegahs of poppy and convicted 277 persons of illegally cultivating, and what is perhaps worthy of remark, in every instance the individuals have confessed the crime, stating they were ready to pay the fine, to which they appeared quite indifferent, imprisonment being the only punishment they really seemed to dread. ${ }^{32}$

Rungpore, 28.8.1820, para. 4; Chaudhuri, Growth of Commercial Agriculture in Bengal (I $757-1900)$, p. 8.

${ }^{30}$ OIOC, Bengal Board of Revenue, Cons. 28.5.1822, No. 101, To Board of Revenue, from R. P. Nisbet, Collector of Rungpore, 7.5.1822, 1, 2, 4; ibid., pp. ii-iii.

${ }^{31}$ OIOC, Bengal Board of Revenue, Cons. 15.1.1822, No. 25, To the Board of Revenue, from R. P. Nisbet, Ag. Collector of Rungpor, 5.1.1822, para.1; Bengal Board of Revenue, Cons. 15.3.1822, No. 28, To the Board of Revenue, from R. P. Nisbet, Act. Collector of Rungpore, 16.1.1822, para. 2.

${ }^{32}$ OIOC, Bengal Board of Revenue, Cons. $15 \cdot 3.1822$, No. 28, To the Board of Revenue, from R. P. Nisbet, Act. Collector of Rungpore, 16.1.1822, para. 3. 
To his dismay, his visits could not be concealed. In every village, he found that almost half of the crops had already been burnt by the cultivators themselves before his arrival. After three weeks on tour,

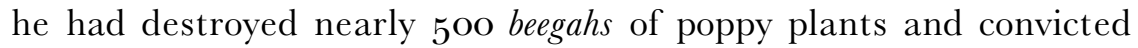
1 , ooo persons for illegal cultivation. The poppy burnt in the fields equalled 75 maunds of opium at the value of Rs 6o,ooo. Adding the amount of poppy that the cultivators burnt themselves, the Collector estimated that no less than 1000 beegahs of poppy had been destroyed. This was equal to 150 maunds or approximately 5.6 tons of opium worth Rs 20,000, indicating a price of Rs 21-39 per kilogram. With hindsight, the calculations that followed seem more than shrewd. The Collector concluded that, having destroyed all the crops and knowing that anyone who was addicted to the drug would never be able to give it up, 'it is not unreasonable to estimate that nearly $15^{\circ}$ maunds of public opium will now be required for the use of this [Rungpore] district consequently the government revenue will be increased nearly 1,20,000 Rs' ${ }^{33}$

On getting these reports, the Board of Revenue seems unsure of whether to praise the resolute Collector or scold him. They could not withhold their appreciation of the Collector's zeal that had animated his hunt for illegal poppy cultivation and the increasing revenues it had brought to the government. The government had certainly insisted on suppressing illicit cultivation by a rigorous enforcement of the law. But they lamented the need for such extensive infliction of penalties and they wanted to make sure that this was not the result of ignorance among the cultivators about the prohibition. Therefore, the Collector was ordered to reduce the penalties and, where fines had already been paid, repay two-thirds of the amount. Similarly, jail sentences should be shortened. By making these adjustments, the board wanted to make sure that the opium cultivators were not deterred from growing the crop in the future, but then under EIC license. At that point, however, the board would not be equally benevolent. ${ }^{34}$

In a short time, the Rangpore Collector turned out to be overly successful. Parallel to his reports on eradication of illicit poppy, the

\footnotetext{
${ }^{33}$ One maund equalled 37.4 kilograms. OIOC, Bengal Board of Revenue, Cons. 15.3.1822, No. 28, To the Board of Revenue, from R. P. Nisbet, Act. Collector of Rungpore, 16.1.1822, para. 4; Bengal Board of Revenue, Cons. 15.3.1822, No. 33, To the Board of Revenue, from R. P. Nisbet, Act. Collector of Rungpore, 7.2.1822, paras $1,3,4$.

${ }_{34}$ OIOC, Bengal Board of Revenue, Cons. 15.3.1822, No. 37, To Acting Collector of Rungpore, from R. Hunter, Secretary Board of Revenue, 15.2.1822.
} 
Board of Revenue received pleas to immediately ship opium, this time into Rangpore. With the fields on fire, sending opium crops grown outside the monopoly into flames, the amount of licensed opium was far too small to meet Rangpore's own demand. Letter by letter, in an increasingly desperate tone, the Collector asked for opium to be sent from Calcutta, as the government stores where running out. However, the Collector thought that the destruction of poppy had been successful, since it had produced 36 new vendors of licensed opium. ${ }^{35}$

The situation in Rangpore district does not immediately fit the general pattern of the opium production and trade that challenged British monopoly. Markovitz speaks of a 'drug frontier' when he explains the production and routes of opium outside British control. Borrowing from the frontier concept, the qualities of simultaneously being a contact zone and a zone 'with a certain absence of state regulation' yet not necessarily ruled by the market, he captures the Malwa opium traded via Sindh and the Portuguese territories. Opium in Rangpore was not characterized by such large-scale operations. And, while the Collector had great trouble controlling the situation, Rangpore was formally under British rule. There was regulation in place-which cultivators did their best to circumvent-and market mechanisms directed opium flows in multiple ways. The native states-Baroda, Kathiawar, Palanpur, Chhota Udaipur, Rajpipla, and Porbandar-had indeed entered into agreements by which they promised to check illicit opium passing through their territories, but they were not particularly committed to enforcing control. Kotah's loss of Rs 6o,ooo as an immediate result of restricted cultivation and the hunt for illicit opium speaks for itself. Perhaps what is most striking is the ways in which the valuable drug could keep small cultivators in Rangpore from poverty. The risks involved in losing the costly crop could, for the poor man, be compensated by even a minimal yield. ${ }^{36}$

Two states within easy reach of Rangpore were Cooch Bihar, neighbouring on its northern border, and Bhutan, further north. The two royal houses had a complicated recent past, including an attempt

${ }^{35}$ OIOC, Bengal Board of Revenue, Cons. 18.1.1822, No. 31, To Board of Revenue, from G. Collins, Collector of Sylhet, 8.1.1822; Bengal Board of Revenue, Cons. 19.2.1 822, No.9, To R. Hunter, Secretary Board of Revenue, from G. Collins, Collector of Sylhet, 31.1.1822; Bengal Board of Revenue, Cons. 5.3.1822, No. 10, To the Board of Revenue, from R. P. Nisbet, Act. Collector of Rungpore, 28.1.1822, para. 6; Bengal Board of Revenue, Cons. 29.3.1822, No. 21, To Board of Revenue, from R. P. Nisbet, Collector of Rungpore, $14 \cdot 3.1822$.

${ }^{36}$ Markovits, 'The Political Economy', p. 106. 
of the Bhutias to capture the Cooch Bihar throne while conquering parts of the kingdom's territory in the 1760 s. The Maharaja of Cooch Bihar had appealed to the Governor General of the EIC, who had sent troops. After having forced the invading army to retreat into Bhutan, a peace agreement of 1774 confirmed the pre-1730 borders between the two polities and, while leaving a garrison in Cooch Bihar, the British army had returned to Rangpore. The price paid by Cooch Bihar for British assistance was the loss of their independence. The treaty turned Cooch Bihar into a minor polity under British protection, paying an annual tribute. Moreover, it secured a trade route for the British between Rangpore and Tibet across Cooch Bihar where the town of Rangpore was a centre of Tibetan trade. Bhutan remained independent from the EIC. It was a theocracy with a dual-authority system: one in the spiritual and the other in the temporal affairs. A. C. Sinha explains that, because of the character of the institutions, the sacred and the secular roles were often mixed up and the head of the temporal institution, the Deb Raja, was de facto the ruler of the kingdom. In the nineteenth century, individual Deb Rajas did not stay long in power. Sinha describes a civil war in which many Deb Rajas were dethroned by competitors. ${ }^{37}$

The EIC was at a bit of a loss as to how to prevent opium from being cultivated in Bhutan and Cooch Bihar and smuggled into Rangpore. It was not a question of reducing the amount of opium produced, but preventing the poppy grown in these states from flooding the markets in Rangpore at much lower rates. An animated dispute broke out in 1822 between the commissioner of Cooch Bihar, the GovernmentGeneral's Agent David Scott, and the Collector of Rangpore R. P. Nisbet. Scott submitted an extensive report on the situation of opium in Rangpore, Cooch Bihar, and Assam, and Nisbet commented on the margin. It gives a good summary of their disagreements and the measures taken to secure the opium monopoly for the Company. ${ }^{38}$

${ }^{37}$ A. D. Sinha, Himalayan Kingdom Bhutan: Tradition, Transition and Transformation (New Delhi: Indus Publishing Co.), pp. 63-72; Sarat Chandra Ghoshal, The History of Cooch Behar: From the Earliest Times to the End of the Eighteenth Century A. D. (State Press Cooch Behar, 1942), pp. 415-417.

${ }^{38}$ OIOC, Bengal Board of Revenue, Cons. 26.7.1822, No. 17, To the Board of Revenue, from R. P. Nisbet, Collector of Rungpore, 19.6.1822, No. 17A, Letter from David Scott, Coach Behar, Commissioner's Office, 15.6.1822, with R. P. Nisbet's comments in the margin. For a study on opium in Assam, see Kawal Deep Kour, 'History of Intoxication: Opium in Assam, 1800-1959', PhD, unpublished (Department of Humanities and Social Sciences, Indian Institute of Technology Guwahati, 2013). 
Nisbet was concerned about the revenues and suggested that Cooch Bihar be put under Regulation 13 of 1816 . This would force the raja to search for and size all opium cultivated outside of the EIC monopoly. The Collector understood that the raja would not agree to this without compensation and he suggested a payment equivalent to the raja's total opium revenues. With prohibition in place in Rangpore but without any control of production in Cooch Bihar, both the cultivation and manufacture of opium would increase in the raja's territories. During negotiations with the Cooch Bihar dewan, the raja's chief minister, the minister explained that the amount of opium that was produced by the opium department was so trifling that payments were unnecessary. Behind such an argument was a concern for the loyalty of the peasants. The dewan did not want to see any restrictions on opium production in Cooch Bihar, since they would injure the cultivators, who would be prohibited from bringing forth such a valuable article. ${ }^{39}$

Scott agreed with the Collector to push for an agreement that prohibited opium in the kingdom. He suggested that a few thousand rupees be paid in return for a written assurance that the illicit poppy had been destroyed. Even if opium production was insignificant at the moment, with prohibition in Rangpore set in force, the raja might not stop an increasing flow of the drug into British territories. Pecuniary remuneration in return for prohibition would make the raja keep the agreement. Nisbet manicured the plan further. Opium cultivation was extensive and the producers in Cooch Bihar would definitely be injured by prohibition. As Collector, he ought therefore to grant licenses to those who wanted to grow and sell the drug in EIC territories, under the monopoly in Rangpore.

Scott, favouring a softer approach, argued against the regulation. It was far too harsh and would put the cultivators to ruin. The raja's accountant ought to oversee the extinction of the plant. But Nisbet, the hardliner, disagreed. If only the raja's officials were honest, no harm would come to the cultivators.

Scott then turned on the whole idea of prohibition. Nothing would be gained, since poppy cultivation would simply move to Bhutan and Assam, away from EIC control. It was on the increase already before the opium agency, and the Burmese would soon discover its value.

${ }^{39}$ OIOC, Bengal Board of Revenue, Cons. 26.7.1822, No. 17, To the Board of Revenue, from R. P. Nisbet, Collector of Rungpore, 19.6.1822, No. 17A, 3.6.1822, From R. P. Nisbet to the Board of Revenue, paras 2, 4, 5, and Remarks by the Collector, para. 2. 
They would establish their own authority over the drug. In Rangpore, however, the government could not possibly continue selling at such exorbitant rates. In the past, not even one-twentieth of the opium that was consumed in the district came from government stores.

Nisbet questioned every step of Scott's argument. He claimed that no goods could be taken undetected from Assam and Cooch Bihar into Rangpore, under the watchful eyes of the Bhutias and Assamese. If manufacture was forced into the plains, away from these communities, as he suggested, illegal production would be detected. It would only take proper management to create considerable revenues. If prohibition was enforced in Cooch Bihar, only legal opium would continue to increase. Scott thought this argument was naïve:

[I] t cannot for a moment be supposed, that any restrictions on the part of our Government can ultimately prevent the introduction of so costly a production as opium, in sufficient quantity for the use of the inhabitants of Rungpore, when a profit of perhaps a hundred per cent may be made by carrying it across an open boundary, and disposing of it whole sale, with little or no risk, to the licensed dealers. ${ }^{40}$

Scott argued for market incentives. He did not believe in Nisbet's iron-fist methods. By reducing the fixed price on government opium to half, it would compete better with illicit opium without increasing the 'destructive practice [of] using the drug'. By taxing the shop or the licence and not the legal vendor, legal and illicit vendors acting in collusion could be prevented. The price paid by the vendor for procuring the opium should be so low that smuggling would no longer be profitable. ${ }^{41}$

\section{A clash of interests in the Company}

The political geography of local trade was on the side of the smugglers. Opium found its way in and out of Rangpore to Assam, Cooch Bihar, and Bhutan. Apart from some hill passes, there were few natural check-points. Nor did the structures of authority over land provide

${ }^{40}$ OIOG, Bengal Board of Revenue, Cons. 26.7.1822, No. 17, To the Board of Revenue, from R. P. Nisbet, Collector of Rungpore, 19.6.1822, No. 17 A, Letter from David Scott, Coach Behar, Commissioner's Office, 15.6.1822, para. 7 .

${ }^{41}$ OIOC, Bengal Board of Revenue, Cons. 26.7.1822, No. 17, To the Board of Revenue, from R. P. Nisbet, Collector of Rungpore, 19.6.1822, No. 17A, Letter from David Scott, Coach Behar, Commissioner's Office, ${ }_{15} .6 .1822$, para. 8. 
any obvious boundaries or customs points. The zamindari estates of both Cooch Bihar and Bhutan were intermingled and, in some cases, estates were insulated by other possessions and boundaries between the different polities could not easily be drawn. ${ }^{42}$

The problem with wiping out opium by prohibitions and punishment was the scale of the trade. In countless ripples of small-scale commerce, petty dealers in salt, tobacco, and sugar brought opium into Assam and Bhutan in small canoes. As Scott would later explain, they hawked their goods about from village to village. The capital of each trader did probably not exceed Rs 10 and the value of their boats was so trifling that confiscation was a toothless measure. A man could easily buy a new boat from the profit of only a few kilograms of illegal opium. The only way in which to destroy the whole poppy crops was to outbid the cultivators' bribe to the amin who paid him to secure their crops from destruction. Scott wanted the Company to give the amin a premium on every burnt field that matched the trifling sums that the cultivators were able to pay him. ${ }^{43}$

The monopoly remained unsuccessful in this part of British India for many years to come, if it ever succeeded to break the local and regionally fractured transactions. Already, within a year after the regulation of 1823 , the campaign to root out unlicensed production and trade fell into the background when war broke out with Burma. Over half a century, the Ahom kingdom in Assam was weakened, first by a rebellion in the last three decades of the eighteenth century and thereafter by three successive Burmese invasions leading on to the war that challenged the EIC's forces on three fronts, from Arakan to upper Assam. After the war, from the late 1820 , British presence and control of the territories from the Brahmaputra to the Burmese borders were significantly strengthened. ${ }^{44}$

${ }^{42}$ OIOC, Bengal Board of Revenue Lower Provinces, Cons. 6.5.1823, No. 32, To Secr. to Board of Revenue, from David Scott, Commissioner Cooch Behar, 13.8.1822, para. 5 .

${ }^{43}$ An amin was a revenue official, revenue surveyor, or investigator in court. OIOC, Bengal Board of Revenue Lower Provinces, Cons. 6.5.1823, No. 32, To Secr. to Board of Revenue, from David Scott, Commissioner Cooch Behar, 13.8.1822, para. 5 and P.S.; Bengal Board of Revenue, Cons. 26.7.1822, No. 17A, To R. P. Nisbet, Esqr., Collector of Zillah Rungpore, from D. Scott, Coach Behar, Commissioner's Office, 15.6 .1822 , para. 7 .

${ }^{44}$ Cederlöf, Founding an Empire, pp. 4, 234; Suryya Kumar Bhuyan, Anglo-Assamese Relations, I 77I-I 82 6: A History of the Relations of Assam with the East India Company from I 77 I to I826, Based on Original English and Assamese Sources (Gauhati: Department of Historical and Antiquarian Studies in Assam, 1949), Chapter 8, p. 2, Chapter 9. 
In 1830, when assessing Assam's still slowly recovering economy, David Scott suggested an initiative to facilitate and encourage agrarian production. Assamese cultivators should be encouraged to produce more crops for export: silk and opium. Neither of the crops was new to the region but the scale was thought to be far too low. The Board of Customs, Salt and Opium agreed. There was no reason for opium sales not to increase. The revenues were good. For 1828-29, opium revenues from licensed production showed a net profit of Rs 22,490 after the Collector's commission and purchase and establishment costs of Rs 7,679 had been withdrawn. The board calculated possible future net profit from public sales to reach Rs 48,000 , if only the officers set their mind to it. As of now, nothing had been sold. But, more important than raising the profits in public sales, the board argued, producing larger quantities of the Bengal opium would provide a means by which the Company could drive the Malwa and Turkey opium out of the China market. But keeping an imperial bird's eye view on the region, they thought Scott was far too lenient towards the cultivators' interests. In order to succeed on the China question, opium sales in Assam had to increase massively while prices had to be kept low. ${ }^{45}$

The disagreement between the Calcutta high command and the officer in charge of Assam reflects their different scale of operation. Scott explained that general poverty prevented any harsh policy to be implemented. There was a scarcity of coins and trade was in many parts of the district in the form of barter. The revenue accountants and landlords in turn found it difficult to convert such payments into cash, and were often forced to discharge private property in order to pay government dues. The situation was caused by the British omission of the old system of paying taxes by labour: the paik. Without increasing available currency, even trifling tax amounts could not be paid. And, in Assam's agrarian economy, it was not possible to produce grain at any

${ }^{45}$ OIOC, Board's Collections, 1832-1833, Bengal Separate Department, No. 28, Relative to a proposition for the provision of Opium in Assam, Extract Proceedings of the Board of Customs, Salt and Opium (Opium Department) Bengal, Consultation 9.6.1830, No. 14, Extract Territorial Department No. 189. From D. Scott Esquire Agent to the Governor General in the North Eastern Frontier, to George Swinton Esquire, Chief Secretary to Government Fort William, 17.4 1830, para. 5; Consultation 20.9.1830, From H. M. Parker, Secretary to Board of Customs, Salt and Opium, to D. Scott, 23.9.183o, para. 3. Carl Trocki observed the British East India Company's decision to meet the Malwa competition in the 1830 s by rapidly increasing their own production. Carl Trocki, Opium, Empire and the Global Political Economy: A Study of the Asian Opium Trade, I750-1950 (New York and London: Routledge, 1999). 
quantity, as there were no buyers and hardly any boats for transport of such cheap and bulky commodities. Scott concluded that taxes needed to be reduced, not raised. The only way forward was to introduce production of costly articles that brought in money payments. To his mind, market incentives were the only means by which this could be achieved, namely to sell at higher prices, not lower. ${ }^{46}$

The board preferred to differ. The quality had to be secured at no more than 30 per cent evaporation (or 70 degrees consistency) of the opium delivered and there were to be no special prices for opium from Assam. The opium, packed into cakes and covered by leaves that secured the moist texture, and where quality could be controlled during packing and transport, was to be guaranteed. Making a comparison with Rangpore, where cultivation was said to have been abandoned due to an unfavourable climate, mismanagement, and dilution of the drug, and where illicit trade caused general losses, the board made no secret of their preferences. The opium trade was all about profit from high-quality and secure deliveries. It had nothing to do with economic uplift of a war-torn region in British India. ${ }^{47}$

The comment provoked Scott, who explained that the cultivators preferred to consume or dispose of the drug rather than delivering it to the government at less than the cost of investment and at only onethird of its current value. In addition, since Assam was not under the EIC monopoly, it lacked the negative consequences of smuggling and the extended use of opium that follow from illegal activities, such as those in Rangpore district. But moral arguments did not impress the board. Sweeping such arguments off the agenda, they bluntly asked for the quantities that Assam was able to produce and for the means by which illicit trade from Assam to the Bay of Bengal and Malacca could be prevented. ${ }^{48}$

${ }^{46}$ OIOC, Board's Collections, 1832-1833, Bengal Separate Department, No. 28, Relative to a proposition for the provision of Opium in Assam, Extract Proceedings of the Board of Customs, Salt and Opium (Opium Department) Bengal, Consultation 9.6.1830, No. 14, Extract Territorial Department No. 189. From D. Scott Esquire Agent to the Governor General in the North Eastern Frontier, to George Swinton Esquire, Chief Secretary to Government Fort William, 17.4 1830, paras 4, 5, 14 .

${ }^{47}$ OIOC, Board's Collections, 1832-1833, Bengal Separate Department, No. 28, Relative to a proposition for the provision of Opium in Assam, Extract Proceedings of the Board of Customs, Salt and Opium (Opium Department) Bengal, Consultation 27.7.1830. From H. M. Parker Esquire, Secretary to Board of Customs, Salt and Opium, to D. Scott Esquire, 24.7.1830, paras 3, 4 .

${ }^{48}$ OIOC, Board's Collections, $1832-1833$, Bengal Separate Department, No. 28, Relative to a proposition for the provision of Opium in Assam, Extract Proceedings of 
As was a common feature in colonial transactions, officers at different levels of the bureaucracy disagreed on priorities and concerns for the people on the ground-the Company's subjects. The further away from the drug and its effects on people, the stronger the tendency to see opium as a commodity among others, only to be assessed at the exchequer's office. The references to the injurious effects on human health are often quickly glossed over. The extensive use of opium, even among children, is rather pleaded as an excuse for extending the monopoly and supply of the drug in the market. People were anyway using it, irrespective of the Company's dealings. The Company was, so to speak, simply clearing up illegal production and marketing, basically doing good for the people.

Closer to the everyday life of villagers, reports were quite different. Opium rapidly found its way along the veins of war and commerce, which dramatically changed conditions. One decade after the war with Burma, the Company sent expeditions up the Irrawaddy to explore the country's trade, markets, and social life. What they found was an economy partly in ruins. Chinese merchants were the wealthiest among the population in the market towns, while the aristocratic estates showed signs of decline. Civil war was rapidly growing, headed by warring factions of the royal family. Northern Burma was no longer under Burmese control apart from the tracts nearest the provincial centres and river courses. No governor moved in his territories without the protection of several hundred soldiers. Singpho communities controlled the tracts farther north and the Hukawng valley. In these towns and villages, Assamese people captured during the war constituted up to three-quarters of the population-'slaves', as the British called them. Also here, the consumption of opium was widespread. The Singpho blamed the many conflicts in the region on 'the brutalising effects of opium and spirits'. ${ }^{4}$

In 1837 , a survey expedition, on its way to determine a border between north Burma and upper Assam, repeatedly reported on the situation of the impoverished Assamese and on opium cultivation. The drug was definitely not new to the kingdom of Burma but, in these tracts, remote from the royal centre, it seems to have been

the Board of Customs, Salt and Opium (Opium Department) Bengal, Consultation 31.8.183o, From D. Scott Esquire, Commissioner of Assam, to H. M. Parker Esquire, Secretary to Board of Customs, Salt and Opium, 19.8.183o, paras 3, 4; Consultation 20.9.1830, para. 4 .

${ }^{49}$ Cederlöf, Founding an Empire, pp. 94, 97, 99, 103. 
introduced only recently. It was said to have arrived with the Assamese, who were addicted to the drug. The British officer concluded that the cultivation of poppy was now irreversible. Every village carefully fenced its plantation and, apart from rice, cotton, and pumpkin, it was the only cultivated plant he could detect in the region. There was a simple method of procuring the drug in these northern parts of Burma, which was also common among poor opium addicts in Assam. The drug was released by incising the green capsules and wiping off the juice with coarse cloth. This was then left in the sun to dry and was thereafter sold to be smoked. The valuable crop quickly found new vendors. A Shan couple who said they travelled for their own amusement explained that they combined pleasure with business and sold tobacco and opium that they obtained from Chinese merchants. Against this background, the British officer's concluding point seems rather naïve: 'Spirit and opium should be prohibited because I think such trade however profitable to individuals, shall be by all means discouraged by the Government.' His opinion had no effect on British policy until after the second Anglo-Burmese war. Until 1860, there was no restriction on opium production in Burma. ${ }^{50}$

These regional and local opium politics were never isolated. Parallel and deeply related to the disputes over the opium fields in Bengal and Assam, the British EIC put enormous pressure on China. Production of opium in India and trade in China were closely linked. Running short of silver, opium was made the means of payment for Chinese tea and silk. However, as Carl Trocki and Julia Lovell observe, the EIC officially and via countless producers and merchants handled opium production in India up to the auctioning-off of the product at Calcutta. From then on, private traders brought the opium to the coast of China. Here, Chinese wholesalers paid in private trading offices with silver for certificates to purchase opium. In turn, silver that originated in China bought Chinese tea for the English market without the EIC

\footnotetext{
${ }^{50}$ Ibid., p. 101. The opium-soaked cloth was sold at three-quarters of a rupee per 16 inches long and two fingers' broad material. The leaves were also consumed as a vegetable and were in that form without narcotic substance. National Archives of India, Survey of India, Memoirs, No. 111. Narrative of a journey from Ava to the Frontiers of Assam and back, performed between Dec. 1836 and May 1837, under the orders of Lieut. Col. Burney, Resident at Ava, by Mr G. J. Bayfield of the Medical Establ. of Fort St George, 16.3 and 26.3.1837. Assam State Archives (hereafter ASA), Report of the Committee Appointed to Fnq. into Certain Aspects of Opium and Ganja Consumption I 878-79, para. 5. ASA, Final Report of the Royal Commission on Opium I 895, para. 46 .
} 
getting stained by the dirty trade in opium. In this way, opium became a cornerstone of the British empire. ${ }^{51}$

From the end of the Anglo-Burmese war, British operations on their North Eastern Frontier seemed to happen in rapid succession. However, we must not be too quick to assume a consciously coordinated plan behind them. When the war ended in 1826 , large tracts lay depopulated. People had escaped to save their lives away from the Manipur kingdom in the mountain range, and from Cachar west of the hills and the Kabaw Valley on the Burmese side. The very bottleneck of trade on the central branch of the Southwest Silk Road connecting China and Bengal lay waste.

Simultaneously, big politics were fought over the EIC's mercantile privileges. European mercantile corporations lived from their sovereignties-the Charter Acts that allowed them to keep monopolies in specified spheres of operation. But, from the perspective of mercantile logic, once the EIC received the Mughal diwani grant, they came in control of a monopoly that was larger than the British Isles. Such a massive provocation on the British parliament and monarchy did not stand unchallenged. Step by step, the Company was brought under parliamentary control and, in the end, lost its monopolies. In 1833, when the Charter Act was again to be renewed, they lost the last two: the trade in tea and the trade in China. And, in a stroke, they lost the last bit of sovereign control of the Asian trade on the sea route between Britain and Asia.

These developments altered British interests in Burma. When military, commercial, and botanical surveys were sent into Burma, they searched for minerals and plants to be exploited, the best routes for transport, the quality of markets, and the state of security and armed forces. Thus, they mapped the grounds for controlling the outlet of the Chinese markets via the Yunnan province and the town of Bhamo, on the Burmese side, close to the Chinese border. This was the portal of the land route to south-west China-essential to the British who had lost commercial control on the sea. However, the plans did not materialize easily. Even in 1868 , when this route was again brought onto the agenda, officers complained that the shortcut from Bengal to Kunming and Yangtze remained shut. ${ }^{52}$

${ }^{51}$ Lovell, The Opium War, p. 3. Carl Trocki, 'Chinese Capitalism and the British Empire', paper presented at the International Association of Historians of Asia Conference, Taiwan, Taipei, 6-10 December 2004, p. 4 .

${ }^{52}$ Cederlöf, Founding an Empire, pp. 83, 99, 198, 200. 
The central role of opium in the imperial plans is evident. It is also obvious that the scales of vision collided between officers on different missions. In each district and region, the administrators were anxious about the regional economic developments and how to form a bond of trust with the local elite. In contrast, the bureaucracy at the Governor General's office had imperial perspectives and argued for using the whip rather than carrots in dealings with opium producers. Monopoly and free-market arguments clashed also in Bengal.

All in all, opium was difficult to control. Much was at stake for a small-scale cultivator operating under harsh environmental conditions. But, with a product promising to double investments, people risked their lives already for very small quantities. 